\title{
Firms, do you know your currency risk exposure? Survey results
}

\author{
Claudio Loderer and Karl Pichler*
}

January 5, 2000

*Institut für Finanzmanagement, Universität Bern, Engehaldenstrasse 4, 3012 Bern, Switzerland

JEL classification: G15, G30,

This paper draws on Vontobel (1996). We would like to thank the participants of the LIFE and Journal of Empirical Finance conference on Risk Management in Portugal and the discussant Willem Verschoor. We are also indebted to the seminar participants at the Stockholm School of Economics and at the $7^{\text {th }}$ Finance Workshop of the Studiengruppe für Finanzmarktforschung. We further benefited from the comments of Manuel Ammann, Didier Cossin, John McConnell, Urs Peyer, Dennis Sheehan, Heinz Zimmermann, and, especially, René Stulz. We are also grateful to Petra Jörg and Pius Zgraggen for their generous help, and to Stefan Reusser for computational assistance. 


\title{
Firms, do you know your currency risk exposure? Survey results
}

\begin{abstract}
This paper surveys the currency risk management practices of Swiss industrial corporations. We find that industrials do not quantify their currency risk exposure and investigate possible reasons. One possibility is that firms do not think they need to know because they use on-balance-sheet instruments to protect themselves before and after currency rates reach troublesome levels. This is puzzling because a rough estimate of at least cash flow exposure is not a prohibitive task and could be helpful. It is also puzzling that firms use currency derivatives to hedge/insure individual short-term transactions, without apparently trying to estimate aggregate transaction exposure.
\end{abstract}




\section{Firms, do you know your currency risk exposure? Survey results}

This paper surveys the currency risk management practices of Swiss industrial corporations. Many of them sell most of their output abroad and would therefore seem to be heavily exposed to currency risk. In fact, currency risk can be substantial. Between 1978 and 1996, the Swiss franc experienced dramatic swings in relation to major currencies such as the U.S. dollar, the Italian lira, and the British pound. Comparing highest and lowest exchange-rate levels, the U.S. dollar depreciated by $60 \%$ vis-à-vis the Swiss franc, the Italian lira by $70 \%$, and the British pound by $62 \%$. Moreover, although not as high as those observed in the equity markets, annual currency rate volatilities can be sizable-in the past six years or so, the volatility of the U.S. dollar, for example, has exceeded $12 \%$. The purpose of this study is to examine whether industrials quantify their risk profile.

Risk management can benefit shareholders because of various concavities in the risk profile of firm value [Stulz (1984), Smith and Stulz (1985), Froot, Scharfstein, and Stein (1993), Smith (1993)]. Such a risk profile (RP) maps firm value against unexpected changes in a specific output price or factor cost. RP concavities are brought about by, among other things, direct costs of financial default, transaction costs of outside funding, asymmetries of information between managers and investors, moral hazard, "firm-specific investments" of noninvestor groups such as managers, employees, customers, and suppliers, and convex tax schedules. Accordingly, unfavorable states of the world reduce firm value by more than favorable states of the world raise it. Reducing risk can therefore raise firm value.

Risk management can in principle also benefit large, underdiversified shareholders by reducing their individual risk exposure. Tufano (1996) details the corporate risk management activities in the North American gold mining industry. According to the data, firms whose managers hold more stock manage more gold price risk, consistent with 
the claim that managerial risk aversion affects corporate risk management policy. Risk management can also benefit managers by enabling them to demonstrate their superior abilities in a world in which their performance depends on uncontrollable risks, such as interest or currency risks. In this case, hedging enables managers to "lock in" their superior abilities [Breeden and Viswanathan (1996)].

Most of the literature focuses on firm-value maximization as the ultimate reason for managing risk. Under that assumption, adopting the appropriate risk-protection policy would seem to require knowing the (asymmetric) RP of firm value [see, for instance, Adler and Dumas (1984), Smith (1995), or Stulz (1996)]. The protection policy itself typically boils down to a portfolio of derivative securities because of the low costs of those products. ${ }^{1}$

In fact, knowing the currency RP of firm value is not always necessary [see also Smith (1995)]. Depending on the purpose of currency risk management, it can be simpler for managers to focus on other risk profiles. For instance, to reduce expected taxes in the presence of convex tax schedules, all they need to know is the currency risk profile of taxable income, which maps taxable income against unexpected changes in currency rates. Similarly, to avoid the deadweight costs of external finance, it might be simpler to focus on the RP of the firm's cash flow [Froot, Scharfstein, and Stein (1994), Tufano (1998a)]. We therefore focus on knowledge of the RP of firm value, but inquire also about knowledge of other risk profiles, including that of operating cash flow.

\footnotetext{
1 This conceptual approach to currency risk management (namely the measurement of the currency $\mathrm{RP}$ of firm value and its hedging/insurance with derivative securities) is fairly diffuse and has found its way into the financial management courses of graduate schools. See, for instance, the case study Jaguar plc, 1984 (Harvard Business School, 9290-005) and the associated teaching note (Harvard Business School, 5-290-034).
} 
Our survey shows that, although they claim to manage risk, industrial companies do not know the currency RP of their value. More than half of them do not even know the currency RP of their cash flow. And those that do know have only a rough idea and focus on a horizon of about 12 months. We examine possible reasons, including that industrials do not hedge, that they have reason to believe their exposure is trivial, and that they fail to understand the importance of assessing their risk profiles. None of these rationales matters. There is also no evidence that managers ignore the currency $\mathrm{RP}$ of firm value because they focus on the RP of other variables instead.

As it turns out, Swiss industrials manage long-run exposure with tools such as contractual clauses, money-market hedges, and operating adjustments. We call these tools on-balance-sheet protection instruments to distinguish them from currency derivatives, which are typically reported off the balance sheet. ${ }^{2}$ The availability of these instruments may explain why industrials don't know the currency RP of their cash flow, let alone that of their value. They may simply think they do not need to know. Their approach in managing long-run exposure may consist of two phases. First, firms may choose a contractual, financial, and operating setup to limit whatever currency exposure they have. For example, they may diversify away currency risk by establishing plants or sourcing in different currency areas. Or they may have their foreign subsidiaries borrow in local currencies. After these precautionary measures are in place, companies may simply wait and see. When currency rates change, they may assess the seriousness of the impact, and then react, if necessary, with the appropriate contractual, financial, and operating adjustments. This is the second phase of industrials' currency risk management. A Swiss exporter to the U.S., for instance, may wait for the dollar to depreciate in relation to the Swiss franc, assess the consequences of that depreciation, and, if necessary, take the appropriate measures.

\footnotetext{
2 For the U.S., see also Petersen and Thiagarajan (1998), Tufano (1998b), and Brown (1999).
} 
That could include raising dollar prices, redesigning products to cater to a more price-inelastic clientele, moving production from Switzerland to the U.S., or tying the wages of employees to the dollar. ${ }^{3}$ Firms also hedge/insure individual short-term transactions with currency derivatives. But in doing so they do not appear to rely on an aggregate measure of their transaction exposure.

Overall, the hedging approach we infer from the data is puzzling. Taking into account the RP of firm value (or at least that of cash flow or of transaction exposure) could help firms better calibrate their on-balancesheet hedges and take advantage of currency derivatives.

The balance of the paper is organized as follows. Section one clarifies the terminology. Section two discusses the structure of the questionnaire used in the survey. Section three describes the sample of firms surveyed and provides information about response rates and associated descriptive statistics. Section four documents the finding that industrial firms do not know the currency RP of cash flow or the currency $\mathrm{RP}$ of firm value. Section five discusses possible reasons. Section six documents the on-balance-sheet hedging activities and provides an explanation of why, under this hedging approach, industrials do not quantify their currency risk exposure. Section seven debates the findings' applicability to other countries. Section eight examines whether the information obtained in our survey can be considered accurate, and section eight draws conclusions.

\section{Terminology}

There are many ways in which firms can protect against foreign exchange risk. Bodie and Merton (2000) list four broad possibilities. We use their taxonomy. First, firms can simply avoid risk. That would seem to involve choosing to sell or buy in markets that are not exposed to currency risk.

\footnotetext{
3 The head of the Swiss employers' association of the machinery industry recently discussed tying Swiss wages to the euro to reduce firms' currency risk.
} 
In an open economy, this is almost impossible to achieve since even if firms are able to avoid direct exposure, at least some of their suppliers, customers, or competitors will bear some exposure. Second, firms can reduce the likelihood or the severity of losses. A Swiss company that exports to France can finance some of its operations with French francs or buy materials from French suppliers.

Third, firms can transfer risk to others. There are basically three ways they can do this:

$>$ They can hedge. That means, they can sell potential gains from favorable currency changes to cover losses from unfavorable changes. A Swiss importer, for instance, can enter into a forward contract to buy Italian lire to fund its purchases from its Italian supplier;

$>$ They can insure. This involves paying another party to assume their currency risk. For example, some firms insure with currency options whereas others do so by invoicing in Swiss francs rather than in foreign currencies;

$>$ They can diversify. An importer can source from suppliers in different countries rather than from only one supplier. This diversification spreads risk over different, possibly uncorrelated currencies. The suppliers assume some of the importer's risk since the importer will buy from the suppliers with the more favorable currency rates.

The final approach to risk protection in the Bodie and Merton (2000) classification is risk bearing. Firms can simply decide that the risk they are exposed to is too small to worry about.

\section{Survey characteristics}

The questionnaire consists of 44 questions grouped in 9 sections. No question is open-ended, meaning that firms are asked to check from a fixed set of possible answers the one (or the ones) they agree with (they are always given the option, however, of formulating their own answer if 
the ones we offer do not apply). The questionnaire was sent to the firm's chief financial officer or, if there was no such function, to the controller or the treasurer. The implicit assumption was that these are the persons most likely to have the relevant information. The survey is structured as follows.

Part one is an icebreaker. It asks whether the firm has hedged in the past, what currencies it has hedged, and what parties (shareholders, creditors and financial analysts, among others) are told what the firm does to reduce currency risk.

Part two investigates contractual clauses, money-market hedges, and operating adjustments (e.g., changes in credit policy and product lines, outsourcing), the firm can use to protect against currency risk.

Part three examines frequency of use and type of currency derivatives employed and assesses who in the firm has the authority to trade currency derivatives. Part four inquires how much exposure companies hedge and the role played by expectations in making that decision. Part five asks why companies hedge against currency risk. Part six surveys the variables that companies want to protect against currency risk (operating cash flow, taxable income, firm value, and liquidity, among others) and the time horizon of relevance in hedging operations.

Part seven tests for the qualitative and quantitative impact of unexpected currency swings on the operating cash flow of the firm. Part eight assesses how currency volatility affects firms. Part nine includes questions designed to establish the identity of the person who fills out the questionnaire, assess the validity of the answers, and clarify possible misunderstandings.

\section{Sample construction and descriptive statistics}

The questionnaire was sent to all 165 firms listed on the Zürich stock exchange (ZSE) in 1996 except for banks and insurance companies. For comparison purposes, the same survey was sent to 165 nontraded 
firms randomly selected from the 1994/1995 issue of Kompass' Führungskräfte und Abteilungsleiter. The comparison sample also excludes banks and insurance companies.

Sixty firms ( $36 \%$ of the ones we wrote to) filled out the questionnaire in the listed subsample, and 36 firms (22\%) did so in the unlisted subsample. A total of 43 firms sent back blank questionnaires. Of these, 18 claimed that their currency risk exposure was small, and 12 said they did not have the time to complete the questionnaire. Counting the firms with a small exposure, the response rate is therefore $35 \%-$ namely $\frac{60+36+18}{330} \times 100$. The sample that actually completed the questionnaire consists of 96 firms, for a response rate of $29 \%$. In comparison, the response rate of the 1998 Wharton survey of derivative usage is $21 \%$. The firms that actually completed the questionnaire are the relevant sample here. Its composition by industry is reported in Table 1.

Industry composition of the sample. Sample year 1996.

\begin{tabular}{lc}
\hline Machinery & $20 \%$ \\
Electronics & $15 \%$ \\
Construction & $12 \%$ \\
Food & $11 \%$ \\
Wholesale & $9 \%$ \\
Retail & $8 \%$ \\
Energy & $6 \%$ \\
Chemicals/Pharmaceuticals & $6 \%$ \\
Transportation & $5 \%$ \\
Tourism & $4 \%$ \\
Paper & $3 \%$ \\
Others & $1 \%$ \\
\hline
\end{tabular}

The subsample of listed firms includes some well-known corporations, such as Ciba-Geigy AG, Sandoz AG, Swissair, Oerlikon Buehrle, and Sulzer. The distribution of the sample by total sales is shown in Table 2 (CHF 1 sold for about $\$ 0.67$ at the time). Since nontraded firms are under no obligation to report their financial 
statements publicly, we do not have sales data for 12 nontraded firms. That explains why the sample in Table 2 (84 firms) is smaller than the total sample (96 firms).

Table 2

Sample distribution by value of total sales. Sample year 1996.

\begin{tabular}{lcc}
\hline Total sales value & Number of firms & $\begin{array}{c}\text { Percentage of total } \\
\text { sample }\end{array}$ \\
\hline < CHF 100 million & 17 & $20 \%$ \\
CHF 100-250 million & 14 & $17 \%$ \\
CHF 250-500 million & 19 & $23 \%$ \\
CHF 500-1,000 million & 11 & $13 \%$ \\
> CHF 1,000 million & 23 & $27 \%$ \\
& & \\
Total & 84 & $100 \%$ \\
\hline
\end{tabular}

According to a mean-comparison test conducted for the subsample of listed firms, firms that fill out the questionnaire are significantly larger than firms that do not. The full sample is therefore probably biased toward larger firms. Moreover, since firms with less exposure are less likely to participate in the survey, the sample is also biased toward firms with nonnegligible currency risk exposure. Our sample firms are therefore larger firms with nonzero currency risk exposure. These properties would not be desirable in a study of the representative Swiss firm. But since we are focusing on risk management practices, nonzero risk exposure is actually a desirable characteristic. Moreover, since larger firms would seem to command more resources and therefore be able to afford a more sophisticated risk management approach, larger firms are arguably more interesting in a survey of risk management practices. 


\section{Quantifying economic exposure}

What we would ultimately like to assess is whether industrials ${ }^{4}$ know the currency RP of firm value. Since asking this question directly might not be very useful, we ask a much easier question, namely, we ask them to quantify the exposure of their operating cash flow.

\subsection{Quantifying the RP of operating cash flow}

Specifically, we inquire: "Without the use of currency derivatives, by what percentage would your firm's operating cash flow change if the CHF value of the following currencies changed by plus or minus 10 percent?" Firms are then asked to state their exposure to the risk of unexpected changes in the U.S. dollar, the German mark, the Italian lira, and the French franc (the associated countries are important trading partners of Switzerland). ${ }^{5}$ Their answers are presented in Table 3 . Not even $40 \%$ of the sample firms are able to quantify their exposure: $37 \%$ can do so for the U.S. dollar, 38\% for the German mark, 30\% for the Italian lira, and $28 \%$ for the French franc. These low percentages may be misleading, since not all firms have a significant exposure to all four currencies. Perhaps the firms that know their exposure to, say, the dollar are not concurrently exposed to any of the other three currencies. We therefore compute the number of firms able to quantify their exposure to at least one of the four currencies, but our conclusion does not change much. Only $43 \%$ of the sample firms can do so.

\footnotetext{
4 We refer to our sample firms interchangeably as nonfinancials and industrials.

5 Annual ten-percent changes in currency rates are not unusual. As mentioned above, the annualized volatility of the U.S. dollar during the interval 1990-1997 has exceeded $12 \%$.
} 
Table 3

Ability to quantify the currency risk profile of operating cash flow. Firms are asked to indicate the impact of a $\pm 10 \%$ change in various currency rates on their operating cash flow. The reported figures are percentages of the total sample. Sample year 1996.

\begin{tabular}{lcccc}
\hline & U.S. & German & Italian & French \\
& Dollar & Mark & Lira & Franc \\
\hline Don't know/No answer & $63 \%$ & $62 \%$ & $70 \%$ & $72 \%$ \\
Nonzero exposure & $31 \%$ & $34 \%$ & $17 \%$ & $20 \%$ \\
Zero exposure & $6 \%$ & $4 \%$ & $13 \%$ & $8 \%$ \\
\hline
\end{tabular}

Consistent with the finding that firms do not know the RP of operating cash flow, the proportion of firms that actually protect "likely future foreign currency inflows and outflows, including those that have not been contractually stipulated yet" is only $33 \%$.

It could be that exposure is not significant enough to warrant explicit quantification. We therefore focus on firms that claim to have protected against currency risk in any one of the years 1993, 1994, or 1995. These firms should have reasons to know their exposure. Table 4 below finds out by sorting firms into four groups, depending on whether they protect against currency risk and on their ability to quantify exposure.

Table 4

Protecting against currency risk vs. ability to quantify the currency risk profile of operating cash flow. Firms that protect against currency risk are those that claim to have done so in at least one of the years 1993, 1994, or 1995. Sample year 1996.

\begin{tabular}{|l|c|c|c|}
\hline & $\begin{array}{c}\text { Firms that } \\
\text { do not } \\
\text { protect }\end{array}$ & $\begin{array}{c}\text { Firms that } \\
\text { protect }\end{array}$ & Total \\
\hline $\begin{array}{l}\text { Firms unable to quantify the } \\
\text { currency RP of their operating cash } \\
\text { flow }\end{array}$ & 9 & 49 & 58 \\
\hline $\begin{array}{l}\text { Firms able to quantify the currency } \\
\text { RP of their operating cash flow }\end{array}$ & 1 & 37 & 38 \\
\hline Total & 10 & 86 & 96 \\
\hline
\end{tabular}


As one can see, currency protection is correlated with knowledge of exposure. The two-way contingency table test has a significant Chi-square value with 0.95 confidence. However, the correlation is driven by the fact that $90 \%$ of the firms that do not protect do not know the RP of their operating cash flow. There is little evidence, however, that firms which do protect are more likely to know their RP. In fact, most of these firms, namely $57 \%\left(=\frac{49}{86} \times 100\right)$, do not know their RP. Thus, again, we have to conclude that the majority of firms do not know the currency risk exposure of their cash flow.

We can take the analysis one step further and examine how many firms with a reason to protect against currency risk know the currency RP in question. Table 5 does that by analyzing whether firms that protect for the purpose of "guaranteeing the cash flow (or earnings) necessary to buttress the image of a financially sound corporation" are more likely to know their RP.

Table 5

Protecting against currency risk to guarantee the cash flow (or earnings) necessary to buttress the image of a financially sound corporation vs. ability to quantify the currency risk profile of operating cash flow. Firms that mention the currency risk protection rationale in question are identified as firms that protect to signal financial health. Sample year 1996.

\begin{tabular}{|l|c|c|c|}
\hline & $\begin{array}{c}\text { Firms that do } \\
\text { not protect to } \\
\text { signal financial } \\
\text { health }\end{array}$ & $\begin{array}{c}\text { Firms that } \\
\text { protect to } \\
\text { signal financial } \\
\text { health }\end{array}$ & Total \\
\hline $\begin{array}{l}\text { Firms unable to quantify the } \\
\text { currency RP of their operating cash } \\
\text { flow }\end{array}$ & 35 & 23 & 58 \\
\hline $\begin{array}{l}\text { Firms able to quantify the currency } \\
\text { RP of their operating cash flow }\end{array}$ & 13 & 25 & 38 \\
\hline Total & 48 & 48 & 96 \\
\hline
\end{tabular}

The two-way contingency table test has a significant Chi-square value with 0.99 confidence, but this is mainly because a sizable proportion $(73 \%$ $=35 / 48 \times 100)$ of the firms that do not protect to signal financial health do 
not know their RP. Firms that do protect for that signaling purpose are just about as likely to know their RP as to ignore it. We find similar results when investigating other protection rationales.

There is also reason to believe that whatever exposure knowledge firms have is only approximate, because they apparently consider only their own direct currency risk. They simply ignore the indirect risk [Pringle (1995)] they bear because of the exposure of their competitors, suppliers, or customers. This is what we infer from their responses to the question, "In protecting against currency risk, does your firm take into account the exposure of: (a) your competitors; (b) your suppliers; (c) your customers?". Between $80 \%$ and $90 \%$ of the firms that answer state that they give no or only little consideration to that exposure ( $70 \%$ give no consideration).

Together, these findings suggest that fewer than $50 \%$ of the firms, even of those that claim to protect against currency risk, are able to (roughly) quantify the RP of their operating cash flow. The remainder either do not want to tell, fail to understand the question, or really do not know. We believe it is the latter.

To find out, we separately ask respondents to list the questions they skipped for fear of revealing confidential information. Few questions are listed and, among those that are, the one concerning currency exposure is mentioned in only $5 \%$ of the cases. Thus companies do not avoid mentioning their currency risk exposure because they are reluctant to reveal sensitive information.

We also find little reason to believe that the exposure question is hard to understand because, when asked to list the questions that are unclear, only $12 \%$ of the firms include this particular question. Further, when asked simply to indicate the direction of the impact of unexpected changes in currency rates on their operating cash flow, many of them are able to provide an answer. Specifically, we ask them to graphically indicate the impact of unexpected currency changes (U.S. dollar, German mark, Italian lira, and French franc) on their operating cash flow. Various 
possible graphs are suggested; all respondents have to do is check one or draw their own. Their answers are reported in Table 6.

Table 6

Knowledge of the qualitative impact of a $\pm 10 \%$-change in various currency rates on operating cash flow. The reported figures are percentages of the total sample. Sample year: 1996.

\begin{tabular}{lcccc}
\hline & U.S. & German & Italian & French \\
Dollar & Mark & Lira & Franc \\
\hline Don't know/No answer & $31 \%$ & $36 \%$ & $47 \%$ & $42 \%$ \\
Exporter-like impact & $47 \%$ & $39 \%$ & $29 \%$ & $33 \%$ \\
Importer-like impact & $15 \%$ & $17 \%$ & $4 \%$ & $11 \%$ \\
Zero impact & $7 \%$ & $8 \%$ & $20 \%$ & $14 \%$ \\
\hline
\end{tabular}

Several firms (between $29 \%$ and $47 \%$, depending on the currency considered) draw the profile of an exporter (higher cash flow when the domestic value of the foreign currency increases); in contrast, only between $4 \%$ and $17 \%$ indicate the profile of an importer; and between $7 \%$ and $20 \%$ claim to be unaffected. A sizable majority of firms, $72 \%$, are able to make qualitative indications of their exposure to at least one currency. Interestingly, none of these profiles is asymmetric, contrary to what one would expect if currency risk management increased value. Possibly, 10\% changes in currency rates are not large enough for any asymmetry to materialize, or companies are unaware of asymmetries.

In sum, since it is not a matter of reluctance to answer or failure to understand, it must be thats firms simply do not know the currency risk exposure of their cash flow.

\subsection{Quantifying the RP of firm value}

Since most firms do not know the RP of cash flow, they cannot know the currency RP of firm value either. The reason is that projected cash flows and their sensitivity to unexpected currency changes would appear to be crucial building blocks in the assessment of the $\mathrm{RP}$ of firm value. ${ }^{6}$

\footnotetext{
6 The RP of firm value can be approximated with the covariance between stock returns and changes in forex rates. But, at best, that covariance measures the firm's residual RP, i.e., that which remains after taking into consideration the firm's hedging policy. The problem is that managers would like to know the firm's currency risk exposure before the hedging policy.
} 
That conclusion is substantiated by three additional observations.

First, the risk management horizon is short. Firms hedge/insure foreign-currency-denominated contracts over the next 12 months, and other (noncontractual) cash flows over the next 8 months. Given this seemingly myopic perspective, it is unlikely that they will be interested in the $\mathrm{RP}$ of firm value, since that requires, at least in principle, an unlimited horizon. Second, in some cases firms admit finding it difficult to estimate future cash flows and presumably firm value. Thirty-six out of 96 firms claim that measurement error is the reason they have a short risk management horizon.

Third, firms do not seem eager to disclose their risk management activities to market participants. If the purpose of hedging were to raise firm value, they would volunteer that information to make sure it was reflected in the stock price. To document this phenomenon we asked firms to indicate what parties receive risk management information. The results are shown in Table 7.

Table 7

Parties informed about risk management activities. Sample year: 1996.

\begin{tabular}{lcc}
\hline & Listed firms & Unlisted firms \\
\hline Insiders & $93 \%$ & \\
Senior managers & $69 \%$ & $91 \%$ \\
Directors & & $55 \%$ \\
& & \\
Investors & $25 \%$ & $38 \%$ \\
Stockholders & $26 \%$ & $0 \%$ \\
Debtholders & $33 \%$ & $0 \%$ \\
Institutional investors & $38 \%$ & $4 \%$ \\
Financial analysts & & \\
& & \\
Business partners & $8 \%$ & $0 \%$ \\
Suppliers & $4 \%$ & $3 \%$ \\
Customers & $4 \%$ & $0 \%$ \\
Creditors & & \\
& & \\
\hline
\end{tabular}


As the table documents, risk management information is almost always given to senior management and, at least for traded firms, frequently to directors as well. That is not generally true for investors, however, particularly in unlisted firms. Financial analysts, classified here as investors for simplicity, for instance, receive information from only $38 \%$ of the traded firms and from almost no unlisted firm. Essentially the same conclusion applies to stockholders, debtholders, and institutional investors. This is inconsistent with a concern for firm value. All this could occur because, as Smith (1995) points out, it is difficult for firms to credibly precommit to risk management. But some firms do disclose their risk management activities. In fact, more than $75 \%$ of the listed firms inform at least one of the investor groups in question (not shown). Thus, most listed firms must have found a way to precommit, possibly by building up a reputation for truthful disclosure.

The table further suggests that firms neglect to provide risk management information to suppliers, customers, and creditors. Only one

firm in the listed sample and no firm in the unlisted sample makes a point of disclosing such information to all three of these business partner groups (not shown). Again, this behavior is difficult to understand if the risk management rationale is to maximize firm value. Presumably, suppliers are more willing to do business with a firm able to control its currency risk, and customers value such a firm's explicit and implicit guarantees more highly.

\section{Interpretation}

There are various possible reasons why industrials do not compute their currency RP of firm value (or of their cash flow). Among other things, they might: (1) not protect against currency risk to begin with and speculate instead; (2) fail to understand the relevance of measuring their currency exposure; (3) have reason to believe their currency risk exposure is trivial; (4) believe that unexpected currency rate changes are offsetting; (5) want to reduce the exposure of variables other than firm value; (6) be 
unable to measure their risk exposure with the necessary accuracy; or (7) be reluctant to enter large derivatives positions.

\subsection{Industrials may not want to protect against currency risk}

If firms speculate rather than protect against currency risk, there is no reason why they should know the currency risk profile of their value. ${ }^{7}$ To examine this possibility, one first has to decide where protection stops and speculation begins.

As other surveys show, our firms are guided in their protection decisions by "views" about the evolution of exchange rates. This practice comes close to speculating on the future course of currency rates, unless corporate treasurers are (or think they are) better predictors than the market. In fact, no such views are necessary to design an effective protective policy. For instance, if a Swiss firm wants to shed the currency risk of a claim to $\$ 1$ million in one year, it can sell $\$ 1$ million forward in return for Swiss francs or borrow Swiss francs against the security of $\$ 1$ million in one year. The firm can do this regardless of whether it thinks the dollar will appreciate or depreciate, or whether it has any opinion about the future course of the dollar. Yet $77 \%$ of the firms in the sample either always or often have such views, and, of these firms, $82 \%$ decide the amount of currency exposure to hedge on the basis of those views. ${ }^{8}$ More favorable views are associated with less hedging.

Since it is unclear whether currency risk management based on views corresponds to speculating, we use a somewhat stricter definition of speculation. We ask firms whether they engage in transactions in foreigncurrency-denominated or currency-derivative securities independently of the operating business to take advantage of predicted changes in currency rates. We are careful not to mention the word speculation because of its negative connotation. In contradiction to the speculation hypothesis,

\footnotetext{
7 On the issue of hedging versus speculating, see also Allayannis and Ofek (1996).

8 Dolde (1993) reports similar findings for the U.S.
} 
however, $91 \%$ of the sample firms never or only very rarely engage in such transactions.

Of course, firms might not be telling the truth. This is quite possible, but when we group firms into those that disclose their identity and those that choose to remain anonymous, the two resulting subsamples have the same proportion (10\%) of speculators. If some firms were misrepresenting their speculation for fear of bad publicity, we would expect a lower proportion of speculators in the sample that disclose their identity.

Rather than speculation in the sense defined here, the survey uncovers apparent evidence of widespread currency risk protection activities. When asked if they protected in any way against unexpected foreign exchange rate changes during 1993, 1994, or 1995, the firms answer as shown in Table 8.

Table 8

Currency risk protection frequency by year. Sample year: 1996.

\begin{tabular}{lcccccc}
\hline & \multicolumn{2}{c}{1993} & \multicolumn{2}{c}{1994} & \multicolumn{2}{c}{1995} \\
& \# of firms & fraction & \# of firms & Fraction & \# of firms & fraction \\
\hline Protected & 76 & $79.1 \%$ & 81 & $85.3 \%$ & 81 & $85.3 \%$ \\
Did not protect & 16 & $16.7 \%$ & 14 & $14.7 \%$ & 15 & $15.7 \%$ \\
Do not know & 4 & $4.2 \%$ & 1 & $1.0 \%$ & 0 & $0.0 \%$ \\
\hline
\end{tabular}

As one can see, more than $80 \%$ of the firms report protecting in one of the three years. Moreover, $90 \%$ protected at least once in those years, and $76 \%$ protected in all three years (not shown).

\subsection{Industrials may fail to appreciate the importance of knowing their risk exposure}

One could argue that industrials fail to compute their currency RP of firm value because they do not understand its importance. The hypothesis can be tested, since it implies that more sophisticated companies are more likely to know at least the currency risk profile of their operating cash flow. Presumably, sophistication is a function of the 
available resources. Thus we test whether larger firms are more likely than smaller firms to quantify the currency risk profile of their operating cash flow. We ask firms to quantify the impact on their cash flow of $10 \%$ changes in currency rates and partition their answers by firm size as approximated by annual sales. The results are presented in Table 9 in the form of a two-by-two contingency test. ${ }^{9}$

Table 9

Ability to quantify the impact of unexpected changes in at least one of four currencies (U.S. dollar, German mark, Italian lira, French franc) by firm size. Firm size is approximated by the value of annual sales. Sample year: 1996.

\begin{tabular}{|l|c|c|c|}
\hline & Small firms & Large firms & Total \\
\hline $\begin{array}{l}\text { Firms that do not know the currency } \\
\text { risk profile of their operating cash } \\
\text { flow }\end{array}$ & 21 & 27 & 48 \\
\hline $\begin{array}{l}\text { Firms that know the currency risk } \\
\text { profile of their operating cash flow }\end{array}$ & 21 & 15 & 36 \\
\hline Total & 42 & 42 & 84 \\
\hline
\end{tabular}

As it turns out, the test is not significant with 0.95 confidence (the $\chi^{2}$ -

value is 1.75 , compared with a critical value of 3.84), suggesting that knowledge of the currency RP and firm size are uncorrelated. In fact, the majority, $64 \%$, of large and therefore presumably more sophisticated firms do not know the RP in question. For small firms, the split between those that know and those that don't is 50/50. The same conclusion follows when we examine qualitative knowledge about the currency risk exposure of the operating cash flow. We repeat the test by proxying for the degree of sophistication by whether firms are listed. The results are the same.

9 As pointed out in Section 2, we do not have sales data for 12 unlisted firms. That explains why the sample in the table is 84 firms instead of 96 . 
Consequently, firms that would seem to have the resources to appreciate the importance of assessing currency risk exposure are not more likely to possess that information than other firms. The implication would seem to be that companies do not deem it necessary to know their currency risk exposure. Of course, if they don't know the RP of operating cash flow, it is even more unlikely that they will know the RP of firm value.

\subsection{Industrials' currency exposure may be minimal}

The third hypothesis is that industrial firms' exposure to currency risk is so small that it would be a waste of time to assess it formally. Supporting evidence would seem to come from studies that examine the sensitivity of stock prices to changes in currency rates. Such sensitivity is small not only in the U.S. [Jorion (1990)], but also elsewhere [Bodnar and Gentry (1993)], including in Switzerland [Jacobs (1995)]. According to Jacobs (1995), only an insignificant minority of the firms traded on the ZSE are measurably sensitive to changes in currency rates. Currency exposure is either small to begin with or is reduced by firms' hedging activities. Since, as reported above, the majority of firms do protect against currency risk, we tend to believe that, if currency exposure is indeed small, it becomes so as the result of the firms' protective efforts.

Support for this conclusion comes when we ask firms: "Without the use of currency derivatives, how strong would be the impact on your firm of unexpected foreign exchange rate changes?" The answers are shown in Table 10.

Currency risk exposure without the use of currency derivatives. Sample year: 1996.

\begin{tabular}{lc}
\hline & Percentage of answering firms \\
\hline Very strong & $20 \%$ \\
Strong & $27 \%$ \\
Average & $36 \%$ \\
Weak & $16 \%$ \\
No impact & $1 \%$ \\
\hline
\end{tabular}


Only $17 \%$ of the firms think their exposure is small. The rest claim to have at least average exposure and would therefore appear to have good reason to measure it.

\subsection{Firms may believe that unexpected currency rate changes are offsetting}

We have argued that managing risk can add value because of concavities in the risk profile of firm value. Consequently, if our firms believe that changes in foreign exchange rates are offsetting in the short run, risk management has little justification. Consistent with that, we find that 24 of 96 firms (25\%) do not protect long-term cash flows because they believe that positive and negative currency rate changes cancel each other out. But if they believe that, why do they protect at all—or, at least, why do they set up long-term operating hedges, as we will see subsequently? Furthermore, how can they tell that their exposure is symmetric if they cannot quantify it?

\subsection{The currency $R P$ of firm value may be the inappropriate risk profile to consider}

The currency RP of firm value is not necessarily what firms have to know to manage their risk effectively. In fact, only $28 \%$ of the firms in the sample want to protect firm value directly. Moreover, when asked to indicate the single most important target, only $1 \%$ of the firms indicate firm value. That could be yet another reason why firms do not compute their RP. Depending on the source of benefits they hope to reap from currency risk management, it can be simpler to focus on the RP of other variables. Although many possible variables come to mind, we restrict ourselves to three: taxable income, liquidity/operating cash flow, and value of contractually set transactions. 


\subsubsection{Currency risk profile of taxable income}

If the rationale for managing risk is to reduce taxes [Smith and Stulz (1985)], it makes more sense to focus on the currency RP of taxable income than on that of firm value. With progressive marginal tax rates, it is by reducing the currency risk exposure of taxable income (really, the currency-induced volatility of that income) that firms can reduce their expected taxes. We can shed light on this hypothesis by investigating why firms engage in currency risk management.

Table 11

Top six and bottom four reasons for managing currency risk. The significance test examines whether the first reason in the table [Guaranteeing the cash flows (or earnings) necessary to buttress the image of a financially sound corporation] is mentioned more frequently than other reasons. Sample year: 1996.

\begin{tabular}{lcc}
\hline & $\begin{array}{c}\text { Percentage of } \\
\text { answering } \\
\text { firms }\end{array}$ & $\begin{array}{c}\chi^{2} \text { - comparison } \\
\text { test } \\
\text { (confidence } \\
\text { level) }\end{array}$ \\
\hline $\begin{array}{l}\text { Guaranteeing the cash flows (or earnings) necessary } \\
\text { to buttress the image of a financially sound } \\
\text { corporation }\end{array}$ & $67 \%$ & - \\
$\begin{array}{l}\text { Reducing financing costs } \\
\text { Guaranteeing the cash flows necessary to meet debt } \\
\text { service and debt repayment (Note: this is not to } \\
\text { suggest your firm is in financial trouble. We only } \\
\text { want to know whether you hedge to prevent that } \\
\text { situation, however remote, from occurring) }\end{array}$ & $50 \%$ & $>0.95$ \\
$\begin{array}{l}\text { Simplifying planning } \\
\begin{array}{l}\text { Guaranteeing sufficient liquidity to finance future } \\
\text { projects/investments }\end{array}\end{array}$ & $41 \%$ & $>0.99$ \\
$\begin{array}{l}\text { Guaranteeing the cash flows (or earnings) necessary } \\
\text { to raise the perceived value of any services and } \\
\text { guarantees the firm is promising its customers }\end{array}$ & $32 \%$ & $>0.99$ \\
$\begin{array}{l}\text { Preventing losses that could potentially discourage } \\
\text { or alarm creditors }\end{array}$ & $15 \%$ & $>0.99$ \\
$\begin{array}{l}\text { Preventing losses that could potentially discourage } \\
\text { or alarm customers }\end{array}$ & $12 \%$ & $>0.99$ \\
$\begin{array}{l}\text { Reducing the risk of large stockholders } \\
\text { (blockholders) }\end{array}$ & & $>0.99$ \\
Reducing taxes & $9 \%$ & $>0.99$ \\
\hline
\end{tabular}


Table 11 reports a list of the top 10 rationales for currency risk management along with the frequency with which they are cited by the answering firms. The results reject the notion that firms manage currency risk for tax-reduction purposes. The main reason for currency risk management is to guarantee the cash flows (or earnings) necessary to buttress the image of a financially sound corporation. All other motivations reported in the risk management literature are mentioned significantly less often. Tax reduction is the least frequently mentioned motivation, acknowledged by only $7 \%$ of the firms.

The reason firms do not manage currency risk for tax reasons could be that currency risk has little effect on the volatility of taxable income. Moreover, at least for multinationals, taxes may not be assessed on the firm's consolidated income (as implicitly assumed here) but rather at the level of its foreign subsidiaries.

\subsubsection{Currency risk profile of liquid assets/operating cash flow}

Another purpose of risk management could be to ensure there is enough liquidity for the firm to seize valuable investment opportunities when they arise [Froot, Scharfstein, and Stein (1993) and (1994)]. ${ }^{10}$ Under that scenario, it could be simpler to focus on the cash the firm could mobilize quickly than to concentrate on currency-induced changes in firm value. A first approximation of that cash could be the firm's actual liquidity (cash, tradable securities, liquidable inventories, and available outside funding). Focusing on liquid assets (as opposed to firm value) is particularly reasonable when the firm's illiquid assets cannot be sold without jeopardizing the company's existence.

To test this hypothesis, we can go back to Table 11. According to the information reported there, guaranteeing sufficient liquidity to finance future projects and investments is a motivation for currency risk management for $32 \%$ of the firms. But when we ask firms to indicate their

\footnotetext{
10 A rigorous treatment of liquidity considerations in designing an optimal hedging policy is in Mello and Parsons (1997).
} 
main motivation, only $4 \%$ list this rationale, and only $18 \%$ list it as one of the top three motivations (not shown). Thus a focus on liquidity cannot be the main reason firms do not compute a currency $\mathrm{RP}$ of firm value.

One variation of this hypothesis is that the variable firms focus on to guarantee sufficient funds for future investments is operating cash flow (see also Stulz, 2000, chapter 4). There is some merit to this hypothesis but, as we saw in Section 4.2 above, less than half of the firms know the associated RP. And even when we look at firms with a reason to protect against currency risk, only half know the RP of their cash flow. Moreover, that risk profile is more of a ballpark figure than anything else, since it corresponds to an average hedging horizon of 8 months and excludes considerations of indirect exposure. In sum, this variation of the hypothesis also fails to explain credibly why firms do not know the RP of firm value.

\subsubsection{Currency risk profile of foreign-currency-denominated contracts}

Finally, firms may not compute the currency risk exposure of their value because they focus on transaction exposure instead. To explore this potential attention to transaction exposure as opposed to economic exposure, we ask firms what variables they shield from unexpected currency rate changes. The answers are reported in Table 12.

Almost two-thirds of the answering companies protect individual foreign exchange commitments and claims. In comparison, there is much more reluctance to shield future cash in- and outflows that have not been contractually stipulated yet. Interestingly, only $26 \%$ of these firms focus, and therefore presumably compute, a net figure of aggregate transaction exposure (aggregate foreign exchange commitments minus claims). 
Table 12

Variables companies protect in their currency risk operations. The significance test examines whether the first item in the table (individual foreign exchange commitments/claims) is mentioned more frequently than other items. Sample year: 1996.

\begin{tabular}{lcc}
\hline & $\begin{array}{c}\text { Percentage of } \\
\text { answering firms }\end{array}$ & $\begin{array}{c}\chi^{2}-\text { comparison } \\
\text { test } \\
\text { (confidence level) }\end{array}$ \\
\hline $\begin{array}{l}\text { Individual foreign exchange } \\
\text { commitments/claims }\end{array}$ & $61 \%$ & - \\
$\begin{array}{l}\text { Foreign exchange balances } \\
\text { Likely future foreign currency } \\
\text { inflows/outflows, including those that have } \\
\text { not been contractually stipulated yet } \\
\text { Translation exposure }\end{array}$ & $44 \%$ & $>0.99$ \\
& $25 \%$ & $>0.99$ \\
\hline
\end{tabular}

The focus on transaction exposure can be confirmed by examining what currency derivatives firms trade in. Our sample firms appear to use currency derivatives frequently for risk management purposes: about $50 \%$ use them always or often, and another $27 \%$ use them at times. ${ }^{11}$ The particular types of currency derivatives used are listed in Table 13.

Table 13

Frequency and type of currency derivatives used by industrial firms. The significance test examines whether forwards are used more often than other derivative securities. The figures in the table represent the number of firms that use a particular derivative product as a percentage of the firms that claim to more than occasionally trade in derivative products. Sample size: 75 firms. Sample year: 1996.

\begin{tabular}{lcc}
\hline & $\begin{array}{c}\text { Frequency of } \\
\text { use }\end{array}$ & $\chi^{2}$ - comparison \\
& & $\begin{array}{c}\text { test } \\
\text { (confidence } \\
\text { level) }\end{array}$ \\
\hline Forwards & & \\
Swaps & $81 \%$ & - \\
Options & $45 \%$ & $>0.99$ \\
Futures & $28 \%$ & $>0.99$ \\
\hline
\end{tabular}

11 In comparison, only about half of the firms in the Wharton-Chase study answered "yes" when asked if they used derivative securities. The difference might be due to the fact that the average U.S. firm has little exposure to financial risks. 
Forward contracts are used by $81 \%$ of the firms that use currency derivatives more than occasionally, much more frequently than other currency derivatives, in particular options. This makes sense if firms are confident about the exposure they want to reduce, consistent with the claim that they focus on transaction exposure. In contrast, if firms wanted to reduce economic exposure, we would probably observe more frequent use of options, since economic exposure itself is uncertain [see also Giddy (1988)]. This argument ignores disclosure considerations, however. Firms might prefer forward contracts to options because the former do not show up on the balance sheet [see also Bodnar and Gebhardt (1999), 16].

\subsection{Industrials may be unable to measure their currency $R P$ of firm value with the necessary accuracy}

Concern about measurement error could be a further reason industrial firms do not measure their currency RP of firm value. As mentioned above, establishing a firm's currency RP of firm value requires the following steps: (1) projecting the firm's free cash flows; (2) capitalizing those cash flows to compute firm value; and (3) assessing how unexpected changes in currency rates affect that value. There are several problems in implementing this estimation. First, it is difficult to project the relevant future cash flows. Second, the assets of these firms trade, if at all, in highly illiquid markets. That complicates the assessment of the appropriate cost-of-capital measures. Third, currency exposure changes with the identity and the policies of competitors, suppliers, and customers. Basing risk management on inaccurate measures of risk exposure can lead to seriously flawed hedges that could potentially increase rather than decrease currency risk.

To investigate this hypothesis, we examine the answers to the following question: "In principle, your firm could attempt to shield all future foreign-currency-denominated cash flows over a period of several years. If that is not the case, what are the reasons?" Table 14 lists the 
possibilities we investigate and the frequency with which they are mentioned.

Almost half of the firms profess an inability to measure future cash flows and their currency composition with much precision. This is consistent with the claim that sample companies are afraid of making mistakes in assessing their currency risk exposure. There is also evidence that firms focus on short-term transaction exposure, since $34 \%$ of the firms hedge individual transactions. Note that $29 \%$ of the firm focus on the short term with the argument that any long-term exposure will be reduced with on-balance-sheet instruments.

\section{Table 14}

Reasons for not shielding expected future cash flows over a long time horizon. The significance test examines whether the first reason in the table (inability to measure exposure with much confidence) is mentioned more often than other reasons. Sample year: 1996.

$\begin{array}{cc}\begin{array}{c}\text { Percentage of } \\ \text { answering firms }\end{array} & \begin{array}{c}\chi^{2} \text {-comparison } \\ \text { test } \\ \text { (confidence level) }\end{array}\end{array}$

We are unable to measure the size and the currency of those cash flows with much confidence

We shield individual transactions

We use currency derivatives to protect against unexpected currency fluctuations over a time period necessary to make the necessary operating adjustments

In the long run, currency fluctuations even out Risk management is decentralized in our organization

It would require too large a position in financial derivatives It would be too expensive
$44 \%$

$\begin{array}{ll}34 \% & <0.80 \\ 29 \% & >0.90\end{array}$

$28 \% \quad>0.95$

$21 \% \quad>0.99$

$16 \% \quad>0.99$

$9 \% \quad>0.99$

\subsection{The derivatives hedge may be too large}

Reducing the economic exposure of the firm could require derivatives hedges of substantial proportions. Although this would not be a problem when currencies move against the firm and the derivative securities yield money to cover the losses, there might be a problem when 
currencies move in the firm's favor. In that case, the operational leg of the hedge is more valuable, but the firm has to come up with the liquidity necessary to cover losses on the derivatives leg. The firm might lack the internal liquidity to do so, and it might be unable to liquidate assets without impairing its operations. Take the case of ABB, a producer of, among other things, turbines for power generation. If it needed liquidity to cover derivatives losses, it couldn't sell the machinery used to produce the turbines without compromising its business. A sale-and-leaseback could be the solution, but $\mathrm{ABB}$ might be unable to find a counterparty quickly and at acceptable terms. The firm could in principle also raise outside funds but, because of various frictions in the capital market, that might not always be possible either. Plus, the losses on the derivatives leg might be mistaken for unhedged losses and cause inappropriate policy decisions [see the Metallgesellschaft case as described in Culp and Miller (1995)].

The upshot of all this is that if firms are unwilling to establish the necessary derivatives hedges, there may be no reason to compute a currency RP of firm value in the first place. According to Table 14 above, however, only $16 \%$ of the sample companies are reluctant to hedge future cash flows for fear of having to establish a derivatives hedge of substantial proportions.

\section{On-balance-sheet hedging}

None of the hypotheses about why firms do not know the RP of firm value (or that of cash flow) has much explanatory power, except to some extent the notion that firms choose to concentrate instead on transaction exposure. The problem is that there is evidence that firms are also concerned about economic exposure. This section presents that evidence and uses it to conjecture an additional hypothesis about why firms do not know the RP of firm value (or of cash flow). 


\subsection{On-balance-sheet risk management instruments}

On-balance-sheet risk management instruments include contractual clauses, money-market hedges, and operating adjustments [see, especially, Shapiro (1996)]. They can be used as alternatives to or in addition to currency derivatives to protect against foreign exchange risk. ${ }^{12}$ Their name distinguishes them from derivative securities, which are typically reported off the balance sheet.

Table 15 documents the importance of contractual clauses and money-market hedges as tools to manage currency risk. Money-market hedges are defined in the questionnaire as financing foreign activities in foreign currencies, or lending or investing in foreign currencies to offset liabilities denominated in foreign currencies. ${ }^{13}$ The table shows that money-market hedges are fairly diffuse, as almost $60 \%$ of the firms claim to be using them. Firms also attempt to shed currency risk with contractual clauses that give them the right to choose the currency in which to pay or be paid. Currency risk sharing and various forms of government-sponsored currency risk insurance are also used, but much less frequently.

Table 15

On-balance-sheet tools of currency risk management: Money-market hedges and contractual clauses. Sample year: 1996.

Percentage of firms using these instruments

Money-market hedges $\quad 56 \%$

Choice of currency in which suppliers are paid $\quad 54 \%$

Choice of currency in which customers are invoiced $\quad 51 \%$

Currency risk sharing $\quad 23 \%$

Swiss export risk insurance $\quad 16 \%$

Export risk insurance provided by foreign countries $\quad 9 \%$

12 A rigorous treatment of operational hedging can be found in Chowdhry and Howe (1997).

13 For the use of foreign debt as a hedging device, see also Allayannis and Ofek (1996). 
In addition to using these tools, firms can make several operating adjustments to limit the likelihood or the severity of losses arising from currency risk. Table 16 details their use in reaction to currency fluctuations. Nearly $80 \%$ of firms (not shown) say currency risk induces them to make at least one of the adjustments listed in the table. The use of operating adjustments in anticipation of unfavorable currency fluctuations follows a very similar pattern. If anything, preventive adjustments are used more often than ex-post adjustments.

Table 16

On-balance-sheet tools of currency risk management: Operating adjustments in reaction to currency risk. Sample year: 1996.

\begin{tabular}{lc}
\hline & $\begin{array}{c}\text { Percentage of firms } \\
\text { making these } \\
\text { adjustments }\end{array}$ \\
\hline Pricing policy & $65 \%$ \\
Choice of countries in which to buy inputs & $48 \%$ \\
Credit policy & $41 \%$ \\
Improving productivity & $31 \%$ \\
Choice of countries in which to sell products and services & $31 \%$ \\
Improving the flexibility of manufacturing systems & $20 \%$ \\
Relocating parts of the firm abroad & $18 \%$ \\
Shifting production among plants internationally & $14 \%$ \\
Changing the pace of product/service innovation & $10 \%$ \\
Setting the size of the budget for sales promotion & $0 \%$ \\
\hline
\end{tabular}

\subsection{Firms do not think they need to know their RP}

The preceding section has documented that firms use on-balancesheet instruments to reduce what is essentially economic exposure. Therein could lie the reason they do not know their RP of firm value (or at least that of their cash flow). Industrials may think that they do not need to know their RPs. Their hedging approach can be described as follows.

Firms may follow a two-phased approach to reduce economic exposure with on-balance-sheet tools. First, they may try to reduce currency risk when making strategic decisions using the tools mentioned in Tables 15 and 16. That includes choosing the right suppliers, 
geographic markets, plant location, and pricing policies. No formal calculation of currency risk exposure is involved. All they may try to achieve is to balance foreign currency in- and outflows. Second, they operate with this strategic setup until currency rate changes (beside changes in other market conditions) impose a modification. Here again, firms do not measure RPs of firm value or of cash flow; they simply wait and see. And if the consequences of currency fluctuations are serious enough, they make the appropriate contractual, financial policy, and organizational changes illustrated in Tables 15 and $16 .{ }^{14}$

All this fails to explain, however, why firms simultaneously use currency derivatives to hedge individual short-term foreign-currency transactions. As seen above, the vast majority (85\% among firms that claim to have managed currency risk in any of the years 1993, 1994, or 1995) microhedges or microinsures short-term individual foreign exchange commitments or claims, or foreign currency holdings. ${ }^{15}$

\subsection{Can it be optimal to ignore exposure?}

The crucial question is whether it makes sense for firms to ignore the RP of their operating cash flow, let alone that of their value. In some cases, it is apparent that firms can use on-balance-sheet tools to reduce (not eliminate) their economic exposure without quantifying it. Take the case of the natural shield Nestlé has obtained by setting up plants around the world. This has allowed the firm to diversify away at least some of its currency risk without actually knowing its risk exposure. The situation is akin to that of investors exposed to stock return volatility. Part of that volatility can be shed by diversification, something that does not

\footnotetext{
14 The findings in Brown (1999) are consistent with this argument. See, in particular, p. 27.

15 The microhedging practice was confirmed in a discussion with the CFO of one of the largest Swiss multinationals. Accordingly, depending on his department's views about a particular currency, the CFO hedges the remittence of dividends from subsidiaries. In contrast, royalty flows are not hedged because they are much more frequent than dividends. By the law of large numbers, the argument went, currency rate changes even out.
} 
necessarily require knowledge of actual portfolio return volatilities. Another operating decision that can reduce risk without requiring an explicit estimation of exposure is the matching of foreign-currency denominated sales with foreign-currency denominated costs. This matching can be achieved, for example, by locating production plants or sourcing production factors in the countries where firms sell. Moneymarket hedges, such as the funding of foreign investments with foreign currencies, can also reduce exposure without requiring knowledge of that exposure.

The problem is that a rough estimate of exposure should not be prohibitively expensive to obtain and could be beneficial in better calibrating the use of on-balance-sheet tools. For instance, if firms knew (even roughly) their RP of firm value, they could better determine the amount of foreign currency funding needed to offset the currency risk of foreign operations. Moreover, knowledge of the RP of cash flow could enable firms to use currency derivatives more effectively. If nothing else, focusing on that RP would force them to move away from their microhedging approach to transaction exposure.

\section{Are Swiss firms a special case?}

In assessing the relevance of our findings, one important question is whether they can be generalized. Are Swiss firms a special case? One possible answer comes from reiterating that the sample includes some fairly large multinational corporations, such as Ciba-Geigy AG and Sandoz (now merged into Novartis), Swissair, Oerlikon Bührle, and Sulzer. More importantly, we can compare some of our findings with findings reported elsewhere. Bodnar and Gebhardt (1999), in particular, have surveyed derivative usage in German and U.S. firms. We can use that study for a comparison. 
The more striking similarities between the two studies are:

Like Swiss firms, U.S. and German firms use both currency derivatives and on-balance-sheet instruments to reduce currency risk. This has been observed also, among others, by Petersen and Thiagarajan (1998) and Brown (1999);

In their risk management strategies, U.S. and German firms appear to pursue the same targets as Swiss firms. All firms, regardless of nationality, primarily target accounting earnings and cash flow rather than firm value. In comparison, $83 \%$ of our firms target operating cash flows, and 80\% target earnings.

As in our sample firms, U.S. and German firms hedge/insure transaction exposure, while essentially ignoring translation exposure.

The horizon of U.S. and German firms in hedging/insuring transaction exposure is also not much longer than 12 months. ${ }^{16}$

$>$ OTC forwards are the most frequently used currency derivative in U.S. and German firms. OTC swaps come second (at least for German firms), and OTC options are third. According to Table 13 above, Swiss firms have the same preferences.

So, in general, it would appear that our firms are similar to firms in Germany and in the U.S. One apparent difference is that larger firms in the Bodnar and Gebhardt (1999) study are more likely than small firms to focus on cash flow and firm value. Swiss firms do not share that regularity. Yet, since Swiss companies are more likely when compared with the firms in the Bodnar and Gebhardt study to focus on cash flow and firm value to begin with, it is not clear whether this apparent difference is significant.

\footnotetext{
16It would appear that U.S. and German firms hedge anticipated cash flows that are not contractually committed more often than our firms. We would need more information, however, to make a definite statement.
} 


\section{Accuracy}

The problem with a survey is that the person who fills it out does not necessarily have the relevant information or the motivation to provide careful and truthful answers. Moreover, questions are not always interpreted correctly. We try to gauge accuracy in different ways.

First, we wanted to make sure that the people who completed the questionnaire had the information we were interested in. This is why, as mentioned in Section 2, the questionnaire was sent to the chief financial officer and, if there was no such function, to the controller or the treasurer of the firm. Then we asked firms to tell us who actually filled out the questionnaire. Table 17 provides the details. In the vast majority of the cases (84\%), the answering person is indeed, at least apparently, the CFO, the treasurer, or the controller. Unless people who complete the questionnaire lie or are careless, we should therefore have received accurate information.

Table 17

Position of the person filling out the questionnaire. Sample year: 1996.

\begin{tabular}{lcc}
\hline & Number of observations & Fraction of subsample \\
\hline & 0 & \\
Director & 7 & 0 \\
Senior executive & 49 & $8 \%$ \\
Chief financial officer & 24 & $51 \%$ \\
Treasurer & 8 & $25 \%$ \\
Controller & 5 & $8 \%$ \\
Others & 3 & $5 \%$ \\
No answer & & $3 \%$ \\
& 96 & $100 \%$ \\
Total & & \\
\hline
\end{tabular}

Second, to increase the costs of misrepresentation and induce firms to provide accurate information, we gave them the choice to identify themselves or not. Firms that disclosed their identity faced the risk of possible embarrassment if they answered inaccurately or incompletely, since they did not know what use we would make of their answers. Their identity and what they said could end up in the press, we could come back 
for further information, or we would cross-check their answers with other managers of the firm. In a small country such as Switzerland the potential embarrassment could be significant. Fifty-four percent of the firms elected to identify themselves. But there is no evidence that the questionnaire was filled out by the CFO more often in these firms than in the others. There is also no evidence that these firms took more time to complete the questionnaire. It took them 44 minutes on average, compared with 41 minutes for the remaining firms. The difference is not statistically significant at conventional levels of confidence. The median time is 30 minutes in both subsamples.

Third, we can use the preceding information to test whether the firms that did not identify themselves were less likely, among other things, to provide information about their RP of firm value. As it turns out, there is no statistical difference between the two groups of firms in this respect either. The two groups are equally likely to disclose information about the quantitative and the qualitative currency exposure of their operating cash flow. Information concerning currency exposure would therefore seem to be accurate.

Fourth, the questionnaire contains questions about sales, equity ratios, current ratios, and dividends, which we can verify with published data. This enables us to identify all traded firms in the sample. A large divergence between published and reported data flags firms that did not take the time to provide accurate answers. As it turns out, the correlation between published and reported data is generally fairly high. If we take sales, for instance, the correlation is essentially 1 . The same holds for dividends on registered and voting bearer shares. For equity ratios, the correlation indicates fairly high accuracy as well, although it is comparatively low, 0.91 . The reason could be that there are different ways to compute this ratio. We tried to avoid this problem by providing the necessary definition of equity ratio in a footnote. Still, responding firms could have misunderstood the definition of book value of equity. 
Fifth, we investigate whether the firms that claimed not to know the risk profile of their operating cash flow simply did not want to take the time to provide that information. Again, the evidence rejects this conjecture. These firms took as long as other firms to complete the questionnaire. This holds regardless of the type of information (quantitative or qualitative exposure) requested. Probably, firms that did not provide this information still spent time pondering the question.

Sixth, we asked the respondents to indicate the questions they were reluctant to answer because of confidentiality concerns. Questions about currency exposure, use of derivative securities, use of on-balance-sheet hedging instruments, etc., met with little if any reluctance to answer. The only question that appears to have bothered firms is one asking them to disclose information about the composition of their sales by currency area and the stock ownership by foreign investors. Twenty-two percent of the firms, especially nontraded firms, listed this question as the most bothersome from the point of view of confidentiality - the frequency by sample is $10 \%$ in the traded and $42 \%$ in the nontraded sample. Still, a statistical test shows that these firms are as likely to answer this particular question as other firms. In other words, they tended to provide the information despite their reluctance.

Seventh, we asked the respondents to indicate the questions that were difficult to understand. The only question that appears to have created some confusion was the quantification of the exposure of operating cash flow. But, as mentioned above, that applies to only $12 \%$ of the firms.

Finally, this survey is the second of its kind. Whereas it is different from the preceding one [Scognamiglio (1995)], some answers can be compared. In particular, both surveys find that firms do not know the currency risk profile of their operating cash flow. 


\section{Conclusions}

The purpose of this survey was to examine the risk management policies of industrial firms. The expectation was that they estimate the risk profile of firm value (or at least that of their operating cash flow) and hedge/insure it with derivative securities. That is not what we find. Firms appear to rely on operating tools both actively and reactively to protect against currency risk. Currency derivatives are used mainly to microhedge/microinsure transaction exposure.

Firms do not know the currency RP of their value or that of their cash flow. Apparently, they do not think they need to know. Yet, this approach is puzzling, since knowing their RPs could help firms better calibrate their risk management tools.

Whereas most firms ignore the quantitative dimensions of their RPs, they at least know the direction of the impact of unexpected currency rate changes on their cash flow. Yet, almost no firms are aware of risk profile concavities of the kind postulated in the literature as the reason to manage currency risk to maximize firm value. Firms either fail to properly understand why currency risk reduces firm value or manage risk even when it is unnecessary.

These results raise many questions for future research. One of the most challenging is the apparent overall approach to risk management by firms, namely the reduction of economic exposure with (mostly) onbalance-sheet instruments on the one hand and the short-run microhedging and microinsuring of transaction exposure with (mostly) currency derivatives on the other. What makes this approach particularly puzzling is that it does not seem to rely on even rough quantitative assessments of exposure (of firm, cash flow, or transaction value). We suspect that these observations could be the result of the way firms are internally organized and of the incentives they create for their executives. CFOs and treasurers may have a compartmentalized view of the firm. Their main incentive might be to guarantee sufficient liquidity and borrowing capacity rather than to worry about firm value directly. 
Focusing mainly on transaction exposure might therefore a sensible thing to do (although it is not clear why it would not make sense to aggregate individual foreign currency positions). Only the CEOs and the heads of the various divisions may have the integral view that CFOs and treasurers apparently lack. But the divisions may not have the tools (currency derivatives) or the authority to manage currency risk other than with operating instruments. And the CEOs may not have the proper incentives to reduce currency risk with derivative securities. Moreover, CEOs, like academics, may have only a fuzzy notion of the benefits of currency risk management. 


\section{References}

Adler, Michael and Bernard Dumas, 1984, Exposure to currency risk: Definition and measurement, Financial Management 13, 41-50.

Allayannis, George and Eli Ofek, 1996, Exchange rate exposure, hedging, and the use of foreign currency derivatives, Working paper (Darden School of Business, University of Virginia).

Allayannis, George, 1994, Exchange rate exposure revisited, Working paper (New York University).

Block, S.B., and R.J. Gallagher, 1986, The use of interest rate futures and options by corporate financial managers, Financial Management 15, 73-78.

Bodie, Zvi and Robert C. Merton, Finance, (Prentice-Hall, Upper Saddle River, New Jersey, 2000).

Bodnar, Gordon M. and Günther Gebhardt, 1999, Derivative usage in risk management by U.S. and German non-financial firms: A comparative survey, Working paper (Wharton School, University of Pennsylvania).

Bodnar, Gordon M., and Richard C. Marston, 1998, 1998 Survey of financial risk management by U.S. non-financial firms (George Weiss Center for International Financial Research, Wharton School, University of Pennsylvania).

Bodnar, G. and Gentry, W., 1993, Exchange rate exposure and industry characteristics: Evidence from Canada, Japan and the U.S., Journal of International Money and Finance 12, 29-45.

Booth, J.R., R.L. Smith, and R.W. Stolz, 1984, The use of interest rate futures by financial institutions, Journal of Bank Research 15, 15-20.

Breeden, Douglas and S. Viswanathan, 1996, Why do firms hedge? An asymmetric information model, Working paper (Fuqua School of Business, Duke University).

Brown, Gregory W., 1999, Managing foreign exchange risk with derivatives, Working paper (University of North Carolina at Chapel Hill).

Chowdhry, Bhagwan and Jonathan T.G. Howe, 1997, Corporate risk management for multinational corporations: Financial and operational hedging policies, Working paper (Anderson School, University of California at Los Angeles). 
Culp, C.L., and Miller, M.H., 1995, Metallgesellschaft and the economics of synthetic storage, Journal of Applied Corporate Finance 7, 62-76.

Dolde, W., 1993, The trajectory of corporate financial risk management, Journal of Applied Corporate Finance, Vol. 6, No. 3, 33-41.

Dolde, W., 1994, Hedging, leverage, and primitive risk, Journal of Financial Engineering 4, 187-216.

Froot, Kenneth A., David S. Scharfstein, and Jeremy C. Stein, 1993, Risk management: Coordinating corporate investment and financing policies, Journal of Finance 48, 1629-1658.

Froot, Kenneth A., David S. Scharfstein, and Jeremy C. Stein, 1994, A new approach to risk management, Harvard Business Review, 91-102.

Giddy, Ian H., The foreign exchange option as a hedging tool, in: Joel M. Stern and Donald H. Chew, eds., New developments in International finance (Basil Blackwell, New York, New York), 83-93.

Jacobs, Andreas, 1995, Wechselkursexposure schweizerischer Aktiengesellschaften, Doctoral dissertation (Institut für Finanzmanagement, Universität Bern).

Jorion, P., 1990, The exchange rate exposure of U.S. multinationals, Journal of Business 63, 331-345.

Mayers, D., and C.W. Smith, 1987, Corporate insurance and the underinvestment problem, Journal of Risk and Insurance 54, 45-54.

Mello, Antonio S. and John E. Parsons, Hedging and liquidity, Working paper (University of Wisconsin).

Mian, S.L., 1994, Evidence on the determinants of corporate hedging policy, Working paper (Emory University).

Nance, D.R., C.W. Smith, and C.W. Smithson, 1993, On the determinants of corporate hedging, Journal of Finance 48, 267-284.

Petersen, Mitchell A. and S. Ramu Thiagarajan, 1998, Risk measurement and hedging: With and without derivatives, Working paper (J.L. Kellogg Graduate School of Management, Northwestern University).

Pringle, John, 1995, A look at indirect foreign currency exposure, Journal of Applied Corporate Finance 8, 75-81.

Scognamiglio, Donato, 1995, Motive des Währungsrisiko-Managements, Working paper (Institut für Finanzmanagement, Universität Bern). 
Shapiro, Alan C., Multinational Financial Management, (Allyn and Bacon, Needham Heights, Massachusetts, 1996).

Smith, Clifford W., Jr., 1995, Corporate risk management: Theory and practice, Journal of Derivatives, 21-30.

Smith, Clifford W., Jr., 1993, Risk management and banking, Finanzmarkt und Portfolio Management 7, 12-23.

Smith, Clifford W., Jr., and René Stulz, 1985, The determinants of firms' hedging policies, Journal of Financial and Quantitative Analysis 20, 391405 .

Stulz, René, 1984, Optimal hedging policies, Journal of Financial and Quantitative Analysis 19, 127-140.

Stulz, René, 1996, Rethinking risk management, Journal of Applied Corporate Finance 9, 8-24.

Stulz, René, 2000, Derivatives, risk management, and financial engineering (Southwestern College Publishing, forthcoming).

The Wharton School and The Chase Manhattan Bank, N.A., 1994, Survey of derivative usage among U.S. non-financial firms.

Tufano, Peter, 1996, Who manages risk? An empirical examination of risk management practices in the gold mining industry, Journal of Finance 51, 1097-1137.

Tufano, Peter, 1998a, Agency costs of corporate risk management, Financial Management 27, Spring 98, 67-77.

Tufano, Peter, 1998b, The determinants of stock price exposure: Financial engineering and the gold mining industry, Journal of Finance 53, 10151052.

Vontobel, Erich, 1996, Währungsrisiken-eine empirische Studie, Working paper (Institut für Finanzmanagement, Universität Bern).

Wall, L.D., and J.J. Pringle, 1989, Alternative explanations of interest rate swaps: An empirical analysis, Financial Management 18, 119-149. 